\title{
Global History, Area Studies, and the Idea of Europe
}

\author{
ALESSANDRO STANZIANI \\ EHESS and CNRS, Paris
}

In 1949, Fernand Braudel proposed a view of the Mediterranean in which part of the Muslim World appeared integral to Europe. This was a courageous act. At the very moment when, after the Second World War, Europe was reflecting on its unity and the idea of pan-European institutions was first conceived, Braudel did not think of Europe as stretching only from the northern Mediterranean shores of the North Sea. Instead, he emphasized the unity of the Mediterranean Sea and the structural compenetration of Muslim and Christian societies with their respective values, despite the multiple conflicts that had opposed them over the centuries. He reached this conclusion without reading Arab sources, for which he was strongly criticized. Moreover, later in his life, Braudel would change his mind. In $A$ History of Civilizations, he clearly distinguished the European "civilization" from the Islamic one. He also differentiated between Russian, African, Indian civilizations, and so on.

The question still stands: even if we do not speak of civilizations, is there any specificity of European societies as compared to the Middle-East, Africa, or India?

Here lies our present investigation: not only in Europe, but also in many Asian and American countries, "general history" is often conceived as that country's national history, while "area studies" are divided into separate departments, when they do not belong to other faculties altogether (oriental studies in the West, European studies in Japan and China, and so on and so forth). In the academic arena, generalist historians and global historians are usually contrasted to specialists of specific areas, both unaware that they share more than they imagine. Area studies are identified by their "specificity," a vague, tautological notion in fact not very far from the notion of "civilization," which seeks to relate a country or area to some enduring characteristics. This attitude is rather problematic, insofar as it consciously ignores or even rejects existing connections between areas, foregrounding instead "imagined communities" - nations mainly - or even transnational entities such as Europe. In the latter case, the question is even more intriguing: is Europe one area to be studied like so many others?

In most history departments on the European continent the answer is: No! Europe is History while the history of other regions only can be described as "area studies." Contesting this point of view, Dipesh Chakrabarty famously suggested "provincializing Europe." This suggestion has the benefit of making Europe one

Cromohs (Cyber Review of Modern Historiography), ISSN 1123-7023, 2021

(C) 2021 The Author. This is an open access article published by Firenze University Press under the terms of the Creative Commons Attribution License, which permits use, distribution and reproduction in any medium, provided the original work is properly cited DOI: $10.36253 /$ cromohs-12562 
among other areas, but it also bears the risk of opposing "civilizations," envisaged as static, ideal entities.

As I will suggest here, another option is to examine the idea of Europe itself. This requires historically unpacking this idea while seeking to show, also, the many connections between "Europe" and other parts of the world. Of course, I cannot cover all the possible interconnected fields where the ideas and practices of Europe emerged and evolved, and will focus, rather, on a particular but crucial datum: the writing of history. Criticism of texts, the identification of sources, and general philosophies of history have been major historical expressions of the idea of Europe, as well as an important venue for thinking about the way "Europe" refers to and interacts with other, distinct worlds.

\section{The critique of texts and authority: a European specificity?}

Europe has often been credited - not only by Western historians, but also by some intellectual and political elites in Japan, China and Russia, since the seventeenth century - with the invention of so-called modern historiography, i.e., philology and erudition, and therefore with inventing the critical analysis of texts. Lorenzo Valla's demonstration that the Donation of Constantine was a fake constituted a dramatic turn and paved the way for later religious Reformation. Authority no longer came from the official interpretation offered by the Church, but from philological expertise. According to Valla, truth is not what is said by a religious authority but rather what is proven. Such a perspective on history and philological criticism were part of the larger humanist movement. Was the attitude fostered by this movement distinctive and unique to Europe?

Many scholars and observers think it was, even today. However, this is unlikely to be true. Philological analyses of texts were developed also in China and in the Muslim world since the twelfth century at least and then flourished in Mughal India, the Safavid and the Ottoman Empire. As in Europe, in these contexts "philology" also involved discussions - if not conflicts - over the role of the State and over different interpretations of the Koran, the Vedas or the classics of the Confucian tradition. Moreover, the skills necessary for such analyses circulated between continents, including Europe, as historians and philologists themselves acknowledged. Thus, this was not the time in which the idea of an opposition between European textual criticism, on the one hand, as a foundation of tolerance and "Europe," and Asian or Islamic dogmatism, on the other, took root.

\section{Language, history and empire building}

That the European powers did not distinguish themselves from their Asian counterparts in terms of their ability to criticize "sacred" texts and their inherent authority between the fourteenth to the seventeenth century, does not imply that there were no differences at all. A significant difference was the use of language, law, and religion - the three main fields of textual criticism - as drivers for imperial projects. On this topic, some authors have recently contrasted the universalist 
policies of Asian and Eurasian Empires (Mughal, Ottoman, Russian) with those of Western Europe, keener to subject and exclude the colonized peoples. Certainly, legal, religious, and historical arguments supported the European colonial expansion, precisely in the way it subjected and excluded "others." For example, law was used to justify both the sovereignty of European states over other people and the appropriation of their land.

Again, this sounds politically correct and historically well grounded, but such a view also tends to contrast highly stylized notions of "Asian" vs. "Western" imperial projects. It also misses the fact that in Western Europe, textual criticism could politically serve to claim sovereignty not only over newly annexed territories, but also over the homeland itself. Discussions on the relation of monarchic powers vis-à-vis the Church, or on the relation between Churches, or between monarchies and local authorities, or between a "state" and its military-agrarian elites over the latter's rank and access to property, implied discussions over the authenticity of textual documents. Such multiple acts and conflicts between legitimizing authorities paved the constitution of territorial powers. Does this mean that all European elites shared a similar attitude?

Many early-modern philosophers, historians, and travelogues emphasized the common values of human kind. Bartolomé de Las Casas, Matteo Ricci, Martino Martini, and François Bernier among many others adopted this view. It is therefore not by chance if, in recent years, mostly following Ann Laura Stoler, many historians specializing in the history of Europe have sought to defend these authors against the accusation of Eurocentrism. These scholars argue that it is not necessary to know Chinese to understand how the Jesuits "invented" China. This for two main reasons: first, because the opposition between "Europe" and "China" is itself "an invention," and second, because the knowledge produced by the Jesuits was at the intersection of multiple worlds and relied on the help of and interaction with local actors. Erudition, reflexivity, and philological analysis of some European sources discussing "China" are thus bound together in a new variation of "global history," as it is presented, which seeks to counter the postures of both Chakrabarty and scholars active in area studies. The danger of this approach, however, is to go back to conventional Eurocentrism under a new garb.

\section{Enlightenments: Europe as leader vs. Europe as a global crossroad}

Some authors have accused the Enlightenment as a whole of Eurocentrism; others have highlighted the heterogeneity of Enlightenment thinkers in Europe itself; others still have called attention to the existence of Enlightenment thinkers outside of Europe, even though their methods may have differed from those of their European counterparts ("multiple modernities"), and pointed to the reciprocal influences or the circulation of ideas between different areas of the world. One of the problems with these debates is that they are often teleological and normative; the very possibility of 
identifying multiple modernities implies a general, ahistorical definition of "modernity" itself.

Certainly, in the eighteenth century, encounters with other worlds no longer fueled the same feelings of exoticism and awe they had fueled in the previous centuries. Rather, such encounters raised questions about the values, economic systems, and types of warfare that could dominate, and discussions as to whether or not this new order of priorities was acceptable. In this context, history writing took on a new dimension, especially in political debates. The dispute between the "ancients" and the "modern" was also whether philosophy or philology should be the main tool of historical investigation. Several philosophers rejected what they called antiquarianism and instead insisted that philosophical principles, not artifacts, give history its meaning. What is less known is how much this reorientation of history writing was related to encounters with non-European worlds. As most Enlightenment authors were intent on writing universal histories, the issue of source reliability was crucial with regard to non-European worlds. Writers no longer needed to know languages; on the contrary, they could rely on philosophical reason alone to validate (or invalidate) a source.

This did not necessarily mean that Europe was thought of as the core and unique expression of "civilization." Certainly, some authors reasoned in these terms: Montesquieu contrasted enlightened Europe to Asian despotism, while Voltaire and Cornelius de Pauw insisted that the education of savage peoples had to be based on Enlightenment principles. But other authors, like Pierre Bayle, Piero Giannone or Henri de Boulainvilliers, stressed the parallels, if not the convergence, between Confucianism, Islam and Christianity. They imagined Europe and its history as a crossroad of cultures, not as the core of a worldly Enlightenment yet to come. Both groups reached their conclusion without knowing any of the languages of the cultures and societies they addressed.

\section{Enlightenments: Europe as leader vs. Europe as a global crossroad}

These two tendencies - one relativist and the other Eurocentrically universalist endured in the nineteenth century, but the latter took a decisive lead, at least in Western Europe. In the eighteenth century, the concept of "Europe" could serve to designate either the core of human civilization or a geographical region connected to other worlds, depending on the author. In the nineteenth century, however, the Muslim world, China and India had to be "modernized" according to European values, while areas like Africa or Central Asia were considered as merely embryonic civilizations.

Paradoxically, the identification of more or less "pure" Russian, Chinese, Indian, or Islamic values reflected the shared production of imaginary civilizations in both the "West" and "the Rest," yet their respective "modernity" coming under scrutiny only for "the Rest." The opposition between "us" and "others," although identified as early as the fifteenth century, only became a global attitude in the 
nineteenth century, not before. Yet, Europe was conceptually and empirically a prisoner of the "nation" instead of the other way round. The nation became the dominant level of political projects and historical investigation. Ranke in Germany, Macaulay in Great Britain and Michelet in France all wrote monumental national histories. These authors sought to detach history from its previous revolutionary claims, highlighting instead the nation as the subject of history, archives as the authentic source and philology as the instrument. Archives were equated with "facts" and historical truths, without any critical reflection on the principles governing archive development, or the selection of documents.

In this context, the study of "exotic" languages underwent a transformation. The teaching of oriental languages was introduced in France, Britain and the Netherlands starting in the mid-nineteenth century. It became more current after 1880, in connection with European neo-colonialism, internationalized trade and the vogue of exoticism in Western countries. Oriental studies programs were supported by large-scale publishing and translation projects: the British, Dutch, and to a lesser extent Russians, French, and Spanish, avidly searched for local legal, literary and religious texts in the colonies in order to publish them. These documents are still widely used by historians today both in the West and in its former colonies. Many historians actually make use of these bilingual texts when they produce histories of princely states in the Indian subcontinent, history à parts égales in Southeast Asia or even Africa. Again, as with the studies on early-modern travelogues, these scholars claim that these texts in fact express the mediation between "colonizers" and "colonized" and, as such, that they overcome the opposition between colonial and vernacular sources and texts. This perspective, however, tends to neglect the hierarchies between the actors (and which need not be the line colonizer/colonized).

\section{The silence of history: from a European decline to the European Union}

Warnings about the "decadence" of the West and a clash of civilizations which we hear today have important precedents in widespread attitudes between world wars, as evinced for instance in global history syntheses like Oswald Spengler's Decline of the West. In Spengler's view, Western (i.e., European) civilization was inexorably losing its pre-eminence, undermined by "barbarianism" both within (the First World War) and without (the Bolsheviks, but also, and above all, the "yellow peril"). Several other European authors shared this attitude as the success of Spengler's book confirms.

Against this notion of decadence, some historians held up their faith in a liberal Europe. Lucien Febvre criticized those who, like Spengler and Arnold J. Toynbee, produced general world histories, which he described as "compilations" lacking problematization, and witnessing to their authors lack of historical skills, language and erudition. Marc Bloch, for his part, insisted on linguistic proficiency in The Historian's Craft and in his famous article on comparative history. Language and the identification of Europe were joined together. Bloch excluded Russia from Europe 
and advocated for the homogeneity of a European area centered around Germany and France as the most relevant basis for appropriate historical comparisons.

It is interesting to note that neither the historians who favored erudition nor those who were more under the influence of social sciences or the philosophy of history were able to understand the rise of Nazism and Fascisms - which they viewed as temporary deviations from the European path, insisting instead on the "yellow" or the "red" peril.

After the war, European integration was presented as a reaction to the wartime trauma and a way to overcome it. Yet, history writing was silent about Nazism and Fascism. This was true in the Federal Republic of Germany until the 1960s, in Italy until the 1970s, and in the GDR until the end.

A third major empty space haunted the historical memory in the era of European integration: colonialism and decolonization. In Britain, colonial and postcolonial history fully developed only in the late 1970s, while in France, the debate exploded only during the 2000s, concurrently with the history of the Algerian War and with the history of slavery. Italy and Germany are still currently seeking to strengthen their own colonial histories.

Within this context, area studies were consolidated and transformed. Oriental studies survived nationalisms, totalitarianisms, wars, and reconstruction, while national history was and is still considered synonymous with history tout court. As before, the study of "non-European" languages and civilizations was merely a complement to national or European history, the latter being considered proper History.

However, the colonial legacy, in particular European attitudes, was reproduced also within certain currents of postcolonial thought, and later reflected in nationalist ideas in Africa, Asia or Latin America. As had already happened in the previous centuries, the identification of "Europe" and other areas was reciprocal: while Europe sought to identify itself over the longue durée, new post-colonial historiographies in Asia, Africa and Latin America looked for national identities starting from their opposition to Europe and its Eurocentrism. One sustained the other and vice versa. All these attitudes together would have a major impact after the collapse of the Soviet Union on the building of the European Union in the age of globalization.

\section{The end of history or the end of Europe?}

The end of empires, including the Soviet empire, produced an irresponsible neoliberal enthusiasm in Europe, which entered an enthusiastic wave of liberal globalization and commercial annexation of territories from the former Soviet empire, while seeking to halt migratory flows from the former colonies. Then with the 2008 financial crisis, all this quickly turned into renewed nationalism, a defense of European "values" against the "others." The idea and practice of Europe were thus 
severely weakened, first by neoliberal enthusiasm, then by the resurgence of nationalisms. This trend also influenced the writing of history. In France, this took a particular turn: following a period in which at least some pages on China, Islam or Africa had been added to history textbooks in public schools, the trend is now to go back to national history, with the aim of better "integrating" (or "assimilating") new and old immigrants. In this context, however, we need much more than a "world history of France" or, at the other extreme, a revival of area studies in their classical form.

Some would claim that those views reflect a "clash of civilizations" approach. Although unsound at the time of its publication, Huntington's book became much more relevant after 2008 when the economic crisis and the setback of globalization spurred nationalist approaches all over the world. This means that we need to discuss such an approach carefully: the question is not if, but when and why it may become relevant.

New nationalistic trends seem so powerful nowadays that they even penetrate the field of global history, turning it into something contrary to its initial aim of overturning national Eurocentric histories. In France, historians now speak of a new "global nationalism," exemplified by Patrick Boucheron's Histoire mondiale de la France. It is perhaps not by chance that Boucheron is currently working on restoring the category of "civilization." This approach encounters great success in China, where histories of "global China" are being produced. Italy also embraced this attitude in the Salvini era, as evinced by works such as the Storia mondiale dell'Italia. Just like Boucheron, the main aim was to contrast far-right parties. Yet, good intentions pave the road to hell: the final outcome is yet another kind of nationalistic history putting Italy at the very center of world stage. Meanwhile, conventional historians of Italy discuss the limits of global history without even conveying colleagues from L'Orientale (the Italian equivalent of SOAS).

History teaching and writing requires a double movement. First, area studies (including Europe) should be studied as open areas, interacting with others, not as ideal ahistorical entities. In an ideal academic world, the very notion of area studies should in fact be rendered obsolete. This does not mean rejecting erudition, but on the contrary, adapting philology itself to its multiple meanings.

Second, this movement can be achieved only with the help of the social sciences, which not only need to be "historicized" (as Marx and many others have argued), but also fully integrated into "connected histories." If it seems difficult to still use Weber or Bourdieu, as well as this or that economic model to analyze the planet as a whole, it also seems fruitless to look for pure Indian or Islamic economics. Decompartmentalizing the social sciences, law, and above all economics is just as urgent as moving beyond area studies. 


\section{Further readings}

Berger Stefan, Christoph Conrad, and Guy Marchal, eds, Writing the Nation, 8 vols (Basingstoke: MacMillan, 2008-2010).

Muthu, Sankar, Enlightenment Against Empire (Princeton: Princeton University Press, 2003).

Pagden, Anthony, Lords of All the World: Ideologies of Empire in Spain, Britain and France c.1500-c.1800 (New Haven: Yale University Press, 1998).

Dirlik Arif, Bahl Vinay, and Gran Peter, eds, History After the Three Worlds: PostEurocentric Historiographies (Lanham, MD and Oxford: Rowman \& Littlefield, 2000).

Pollock Sheldon, Elman Benjamin A., and Chang Ku-ming Kevin, eds, World Philology (Cambridge, MA: Harvard University Press, 2015).

Rao Velcheru Narayana, Shulman David Dean, and Subrahmanyam Sanjay, Textures of Time: Writing History in South India, 1600-1800 (Delhi: Permanent Black, 2001).

Stanziani, Alessandro, Les entrelacements du monde. Histoire globale, pensée globale XVIeXXIe siècles) (Paris: CNRS Éditions, 2018).

Woolf, Eric, Europe and the People Without History (Berkeley: University of California Press, 1982).

Alessandro Stanziani is Professor, EHESS, in Global History and Research director, CNRS (alessandro.stanziani@ehess.fr). His main interests and fields are: Global history; Labor history; Russian history, eighteenth-twentieth century; Indian ocean, labor, eighteenth-nineteenth century; Economic, business and labor history, Europe (France, Britain), eighteenth-early twentieth century; Food history, eighteenth-twentieth century. His main individual books include: L'économie en révolution. Le cas russe, 1870-1930 (Paris: Albin Michel, 1998); Histoire de la qualité alimentaire, XVIII-XX siècle (Paris: Seuil, 2005); Rules of Exchange: French Capitalism in Comparative Perspective, Eighteenth to Early Twentieth Centuries (Cambridge, Cambridge University Press, 2012, paperback 2014); Bâtisseurs d'empires, Russie, Chine, Inde à la croisée des mondes, XVe-XIXe siècle (Paris: Liber, 2012); Bondage, Labor and rights in Eurasia from the Sixteenth to the Early Twentieth Centuries (New York, Berghahm 2014, paperback 2015); After Oriental Despotism: Warfare, Labour and Growth in Eurasia (London: Bloomsbury, 2014); Seamen, Immigrants and Convicts in the Indian Ocean, 1750-1914 (New York and London: Palgrave MacMillan, 2014); Labor in the Fringes of Empire: Voice, Exit and the Law (New York and London: Palgrave MacMillan, 2018); Eurocentrism and the Politics of Global History (New York and London: Palgrave MacMillan, 2018); Les entrelacements du monde. Histoire globale, pensée globale (XVTe-XXIe siècles) (Paris: CNRS Éditions, 2018). 